\title{
Publisher Correction: The Bargaining and Contagion Effects of Investors in Single Family Residential Properties: The Case of Denver Colorado
}

\author{
Jeffrey P. Cohen ${ }^{1}$ (D) John P. Harding ${ }^{2}$ \\ Published online: 03 July 2020 \\ (C) Springer Science+Business Media, LLC, part of Springer Nature 2020
}

\section{Publisher Correction: J Real Estate Finan Econ https://doi.org/10.1007/s11146-020-09766-5}

The original version of this article unfortunately contained mistakes. Errors were found within Tables 2, 3, 5, 6 and 7. The corrected versions of these tables are as follows. The Publisher regrets these mistakes.

The original article has been corrected.

The online version of the original article can be found at https://doi.org/10.1007/s11146-020-09766-5

\author{
Jeffrey P. Cohen \\ Jeffrey.Cohen@business.uconn.edu \\ John P. Harding \\ johnh@business.uconn.edu
}

1 Center for Real Estate and Urban Economic Studies, Department of Finance, School of Business, University of Connecticut, Mansfield, CT, USA

2 Center for Real Estate and Urban Economic Studies, University of Connecticut, Mansfield, CT, USA 
Table 2 Estimates of Bargaining Effects

Dependent Variable:

Sale Price (\$)

\begin{tabular}{|c|c|c|c|c|c|c|}
\hline \multirow[b]{2}{*}{ Variables } & \multicolumn{2}{|c|}{ Individual Investors } & \multicolumn{2}{|c|}{ Professional Investors } & \multicolumn{2}{|l|}{ All Investors } \\
\hline & Full Sample & $2003-2016$ & Full Sample & $2003-2016$ & Full Sample & 2003-2016 \\
\hline \multirow[t]{2}{*}{ Lot Size (sq. ft.) } & 3.55 & 3.74 & 3.59 & 3.76 & 3.57 & 3.80 \\
\hline & $(34.21)$ & $(23.52)$ & $(35.32)$ & $(24.41)$ & $(34.80)$ & $(24.45)$ \\
\hline \multirow[t]{2}{*}{ House Size (sq. ft.) } & 89.26 & 109.59 & 89.41 & 109.78 & 88.84 & 109.25 \\
\hline & $(151.91)$ & $(122.17)$ & $(155.74)$ & $(126.25)$ & $(153.02)$ & (124.67) \\
\hline \multirow[t]{2}{*}{ Finished Basement (sq. ft.) } & 36.42 & 41.33 & 35.91 & 40.52 & 36.06 & 40.58 \\
\hline & $(70.28)$ & $(51.46)$ & $(70.82)$ & $(51.99)$ & $(70.39)$ & $(51.71)$ \\
\hline \multirow[t]{2}{*}{ No. of Bedrooms } & -5258.06 & -6217.82 & -5208.23 & -6139.03 & -5182.17 & -6137.06 \\
\hline & $(-16.62)$ & $(-12.31)$ & $(-16.82)$ & $(-12.52)$ & $(-16.57)$ & $(-12.44)$ \\
\hline \multirow[t]{2}{*}{ Full Bathrooms } & 7459.79 & $16,207.32$ & 7829.46 & $16,835.23$ & 8724.74 & $16,847.15$ \\
\hline & (19.85) & $(27.28)$ & $(21.31)$ & (29.17) & (21.07) & $(29.02)$ \\
\hline \multirow[t]{2}{*}{ Half Baths } & 4775.21 & 6098.24 & 5094.00 & 6566.82 & 4888.37 & 6405.74 \\
\hline & $(9.54)$ & $(7.82)$ & $(10.40)$ & $(8.68)$ & $(9.88)$ & $(8.41)$ \\
\hline \multirow[t]{2}{*}{ House Age $(5-10]$ yrs } & $-10,656.72$ & $18,762.03$ & 9991.75 & $71,839.60$ & $-10,305.50$ & $18,147.52$ \\
\hline & $(-7.50)$ & $(-9.27)$ & $(-7.18)$ & $(-9.07)$ & $(-7.34)$ & $(-9.17)$ \\
\hline \multirow[t]{2}{*}{ House Age (10-20] yrs } & $-23,585.88$ & $30,627.37$ & $22,884.69$ & $29,772.14$ & -23.378 .32 & 30.375 .12 \\
\hline & $(-16.87)$ & $(-14.26)$ & $(-16.72)$ & $(-14.28)$ & $(-16.92)$ & $(-14.48)$ \\
\hline \multirow[t]{2}{*}{ House Age $(20-50]$ yrs } & $-23,357.72$ & $47,203.01$ & $51,587.74$ & $45,127.25$ & $-53,100.05$ & $46,297.86$ \\
\hline & $(-37.01)$ & $(-21.08)$ & $(-36.75)$ & $(-20.76)$ & $(-37.27)$ & $(-21.16)$ \\
\hline \multirow[t]{2}{*}{ House Age $>50$ yrs } & $-16,620.80$ & $59,099.47$ & $59,295.26$ & $55,673.59$ & $-60,765.23$ & $56,785.34$ \\
\hline & $(-41.87)$ & $(-26.03)$ & $(-41.16)$ & $(-25.25)$ & $(-41.78)$ & $(-25.59)$ \\
\hline \multirow[t]{2}{*}{ Bargaining Effect } & -1487.01 & -1604.51 & $34,186.72$ & $38,475.28$ & $19,362.83$ & $28,669.60$ \\
\hline & $(-2.81)$ & $(-1.81)$ & $(65.85)$ & $(57.64)$ & $(46.73)$ & $(47.87)$ \\
\hline \multirow[t]{2}{*}{ Demand Effect } & -3752.31 & -7950.33 & $26,092.86$ & $28,817.74$ & $-11,947.08$ & $21,162.17$ \\
\hline & $(-11.23)$ & $(-12.20)$ & $(-51.32)$ & $(-44.10)$ & $(-43.05)$ & $(-47.08)$ \\
\hline \multirow[t]{2}{*}{ Constant } & 130392.92 & $144,555.36$ & $128,402.08$ & $141,975.31$ & $130,196.46$ & $143,602.82$ \\
\hline & (79.94) & $(56.94)$ & (80.67) & $(57.78)$ & $(80.72)$ & $(57.88)$ \\
\hline Observation & 126,351 & 68,745 & 126,351 & 68,745 & 126,351 & 68,745 \\
\hline $\mathrm{R}$-squared & 0.407 & 0.464 & 0.432 & 0.495 & 0.420 & 0.489 \\
\hline Number of Fixed Effects & 3545 & 1790 & 3545 & 1790 & 3545 & 1790 \\
\hline
\end{tabular}

1. All models estimated using STATA's xtreg command including tract by year fixed effects

2. Sample excludes transactions deemed to be REO sales and sales by Financial Institutions

3. Bargaining Effect estimated using (investor seller - investor buyer)

4. House age at sale is measured as sale year less year built. New homes are defined as those with age equal to 0 or 1 year

5. New homes are excluded from the estimating sample because they are not secondary sales (see text)

6. The excluded house age category includes homes older than 1 year and $<=5$ years 


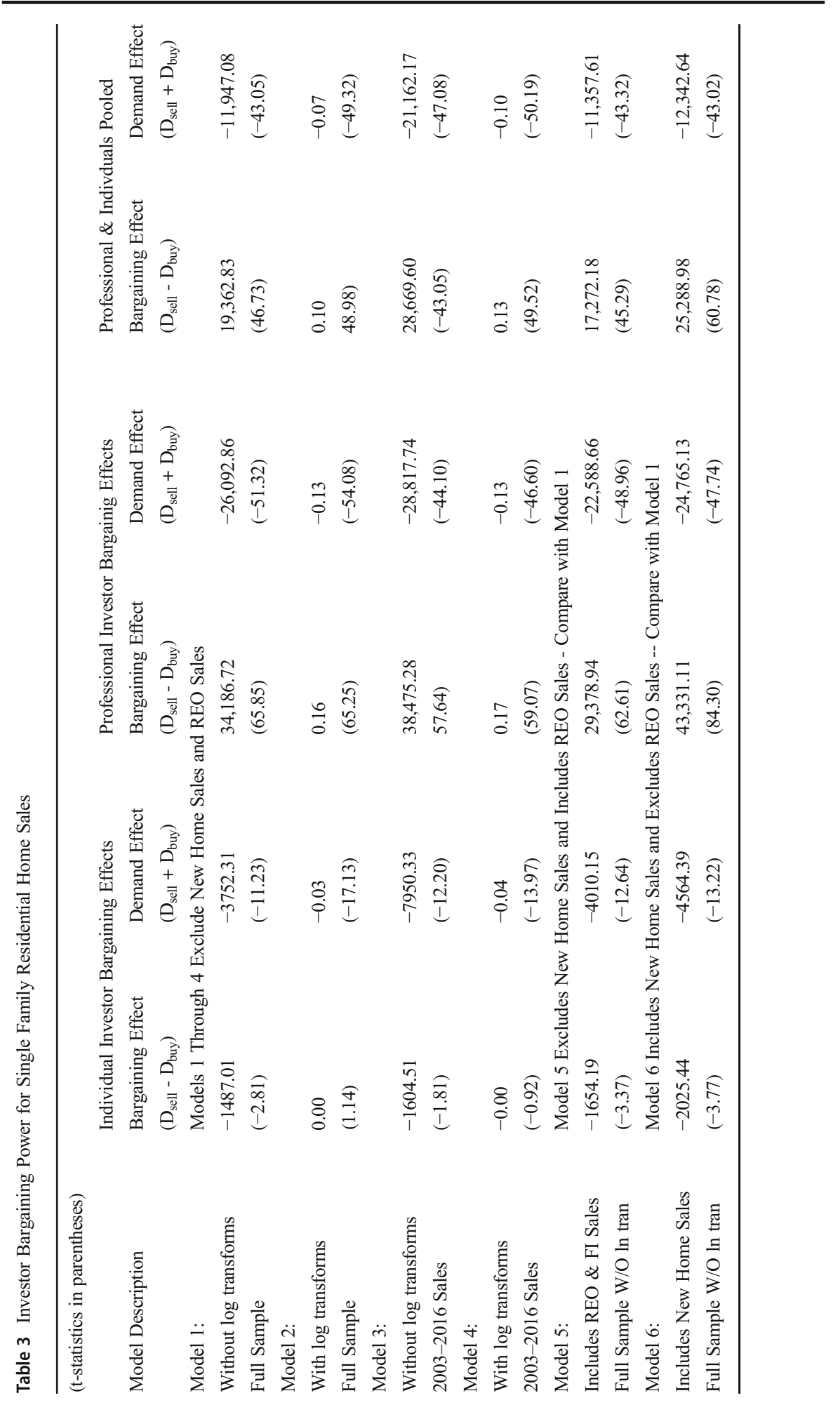




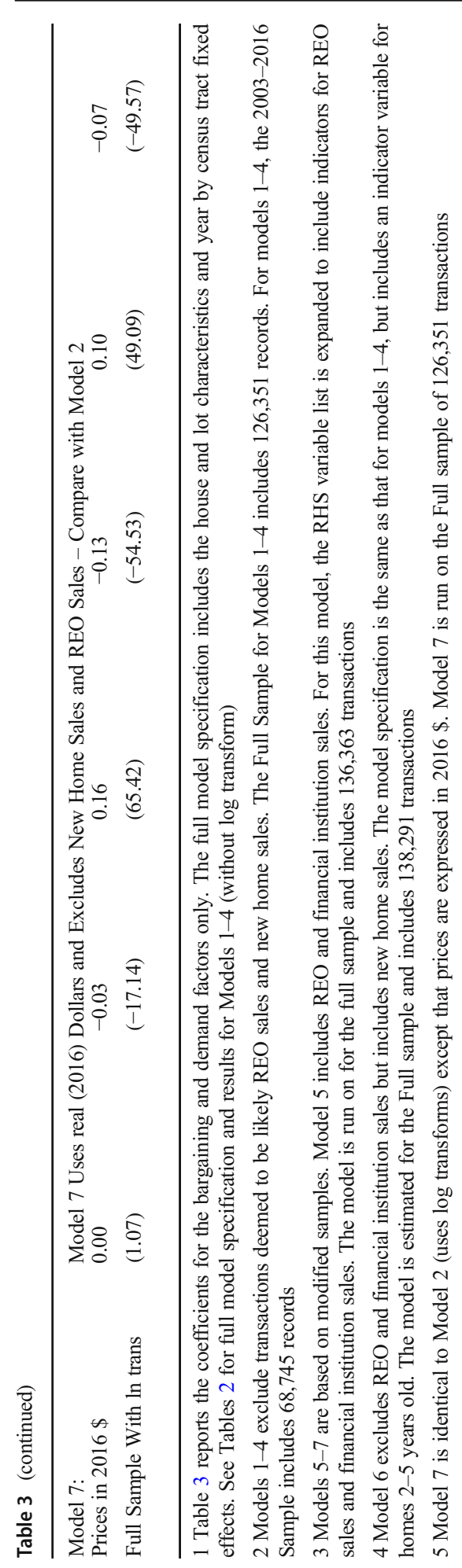


Table 5 Comparison of House Characteristics in Repeat Sales Sample

\begin{tabular}{lllllllll}
\hline & Full Sample & \multicolumn{2}{l}{ Repeat Sales Sample } & Excluded Sample & Difference \\
\hline & mean & s.d. & mean & s.d. & mean & s.d. & mean & sig \\
House Size (sq. ft.) & 1504 & 788 & 1464 & 711 & 1551 & 866 & -86 & $* * *$ \\
Lot size (sq. ft.) & 6769 & 3192 & 6457 & 2440 & 7132 & 3856 & -676 & $* * *$ \\
Finished Basement (sq. ft.) & 398 & 482 & 405 & 471 & 391 & 495 & 14 & $* * *$ \\
House Age (yrs.) & 47 & 32 & 48 & 32 & 46 & 32 & 2 & $* * *$ \\
No. of Bedrooms & 2.79 & 0.84 & 2.79 & 0.84 & 2.83 & 0.86 & -0.04 & $* * *$ \\
No. of Bathrooms & 2.27 & 1.13 & 2.28 & 1.08 & 2.26 & 1.18 & 0.02 & $* *$ \\
Full Bathrooms & 1.95 & 0.89 & 1.97 & 0.85 & 1.92 & 0.92 & 0.05 & $* * *$ \\
Half Baths & 0.32 & 0.50 & 0.31 & 0.49 & 0.34 & 0.52 & -0.03 & $* * *$ \\
No of Observations & 99,817 & & 53,648 & & 46,169 & & & \\
\hline
\end{tabular}

** denotes significance at the $5 \%$ level

*** denotes significance at the $1 \%$ level

1. Table 5 reports house characteristics for the full sample, the repeat sales sample and the excluded sample

2. The "Full Sample" includes all single family houses for which we haveat least one sales transaction between 1986 and 2016

3. The Repeat Sales Sample includes only those houses that have at least one repeat sales transaction that passes filters described in text

4. The Excluded Sample includes houses with only a single sale and repeat transactions that fail the filters described in text

Filters include excluding "flips", excluding sales $<\$ 5000$ or more than $\$ 1,000,000$, excluding new home sales and REO sales

5. Significance is measured by a t-test assuming equal variances. Null is that there is no difference in means for the two subsamples

6. Not all characteristics are known for all houses because characteristics are not required for repeat sales estimates 
Table 6 Summary Statistics for Repeat Sales and Contagion Estimation

\begin{tabular}{|c|c|c|c|c|c|c|c|c|}
\hline \multirow[b]{2}{*}{ Variable } & \multicolumn{2}{|c|}{ Full Sample } & \multicolumn{2}{|c|}{$\begin{array}{l}\text { Individual } \\
\text { Investor Buyer }\end{array}$} & \multicolumn{2}{|c|}{$\begin{array}{l}\text { Professional } \\
\text { Investor Buyer }\end{array}$} & \multicolumn{2}{|c|}{$\begin{array}{l}\text { Owner } \\
\text { Occupier Buyer }\end{array}$} \\
\hline & Mean & $\begin{array}{l}\text { Std. } \\
\text { Dev. }\end{array}$ & Mean & $\begin{array}{l}\text { Std. } \\
\text { Dev. }\end{array}$ & Mean & $\begin{array}{l}\text { Std. } \\
\text { Dev. }\end{array}$ & Mean & $\begin{array}{l}\text { Std. } \\
\text { Dev. }\end{array}$ \\
\hline Purchase Price & $\$ 199,049$ & $\$ 133,419$ & $\$ 169,992$ & $\$ 112,599$ & $\$ 266,526$ & $\$ 180,103$ & $\$ 201,318$ & $\$ 133,362$ \\
\hline Sale Price & $\$ 271,057$ & $\$ 164,735$ & $\$ 234,883$ & $\$ 140,072$ & $\$ 314,689$ & $\$ 205,592$ & $\$ 275,377$ & $\$ 165,771$ \\
\hline Holding Period & 5.86 & 4.29 & 5.10 & 3.95 & 3.40 & 3.48 & 6.08 & 4.33 \\
\hline $\ln \left(\mathrm{P}_{1} / \mathrm{P}_{0}\right)$ & 0.3377 & 0.4217 & 0.3619 & 0.3837 & 0.1788 & 0.5850 & 0.3396 & 0.4194 \\
\hline Avg Annual Return & 7.73 & 10.09 & 9.86 & 10.27 & 12.42 & 21.81 & 7.20 & 9.23 \\
\hline \# of Nearby Houses & 88 & 31 & 88 & 32 & 87 & 35 & 88 & 30 \\
\hline \# of Nearby REOs - $t_{0}$ & 1.05 & 3.01 & 1.06 & 3.02 & 1.29 & 3.27 & 1.05 & 3.00 \\
\hline$\#$ of Nearby REO $-t_{1}$ & 1.63 & 4.06 & 1.24 & 3.32 & 1.19 & 3.03 & 1.72 & 4.20 \\
\hline \# of Nearby Investor-Owned $-t_{0}$ & 13.36 & 11.73 & 15.54 & 12.20 & 21.33 & 27.03 & 12.69 & 10.49 \\
\hline \# of Nearby Investor Owned - $t_{1}$ & 12.84 & 9.99 & 15.58 & 11.16 & 18.25 & 20.92 & 12.18 & 8.97 \\
\hline Change in \# of nearby REOs & 0.58 & 4.62 & 0.18 & 4.08 & -0.10 & 3.90 & 0.67 & 4.73 \\
\hline Change in \# of nearby Investors & -0.52 & 7.18 & 0.04 & 7.59 & -3.08 & 11.39 & -0.52 & 6.88 \\
\hline Number of Observations & 92,753 & & 12,877 & & 2864 & & 76,743 & \\
\hline
\end{tabular}

1. Table 6 presents summary statistics for the sample used to estimate the contagion effect and compares characteristics by the type of buyer at the first transaction

2. Dependent variable is $\ln$ (price1/price0)

3. Columns 3-8 present summary statistics based on the nature of the buyer at the first transaction in the repeat sales pair

4. The number of nearby houses, REOs and Investor Owned Properties are measured using a circle of radius $.2 \mathrm{~km}$ or roughly .12 miles

The number is calculated at $\mathrm{t} 0$, the time the property was bought and $\mathrm{t} 1$, the time the property was resold

5. The changes in number of REOs and Investor Owned Properties are calculated as the number at the acquisition of the property ( $\mathrm{t} 0)$ less the number at the subsequent resale(t1)

6. The holding period is calculated in years as the year of sale ( $\mathrm{t} 1$ ) minus the year of acquisition (t0)

7. The repeat sale regression is run using annual year indicator variables defined in the standard manner is $-1,0$ or 1 depending on whether the property was bought or sold in the given year 
Table 7 Contagion Coefficients (t-stats in parentheses)

$\begin{array}{llll}\text { REO Effect } & \text { Investor Effect } & \begin{array}{l}\text { Average } \\ \text { Annual House } \\ \text { Price App. }\end{array} & \text { Repeat Sales } \\ & & & \\ & & \end{array}$

\section{Model 1}

No Controls for REO or Investor Contagion -

Excludes REO Related at $\mathrm{t}_{0}$

Model 2

Controls for REO \& Investor Contagion

$$
-0.01256 \quad 0.00544
$$

Excludes REO Related at $\mathrm{t}_{0}$

Model 3

No Controls for REO or Investor Contagion

Includes REO Related at $t_{0}$

$\begin{array}{llll}- & - & 5.33 \% & 97,238 \\ - & - & & \\ -0.01291 & 0.00543 & 5.29 \% & 97,238 \\ (24.35) & (-51.04) & & \end{array}$

Model 4

Controls for REO \& Investor Contagion

1. Contagion effects are estimated using the change in the number of in nearby REOs and nearby InvestorOwned Properties as well as the standard repeat sales indicators for the years 1987-2016

2. Models $3 \& 4$ include 4483 records where the initial purchase at t0 appears to be an REO Sale

Publisher's Note Springer Nature remains neutral with regard to jurisdictional claims in published maps and institutional affiliations. 